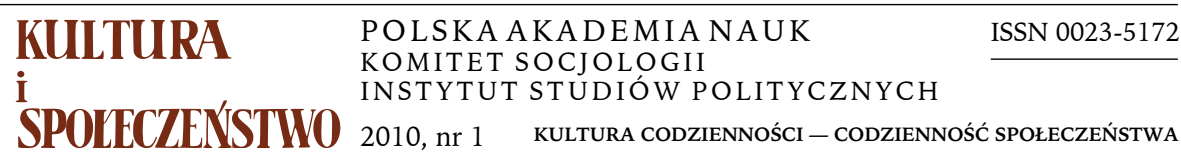

MAREK KRAJEWSKI

Uniwersytet im. Adama Mickiewicza w Toruniu

\title{
SPOSOBY ŻYCIA PRZEDMIOTÓW O TRWAŁOŚCI DÓBR MATERIALNYCH
}

Kiedy używamy przedmiotów, to interesuje nas przede wszystkim ich poręczność i pomocność, a więc to, czy są one w stanie wspomagać nas w realizowaniu zamierzonych celów. Kiedy myślimy o przedmiotach, a czynimy to wówczas, gdy stanowią one dla nas problem, to zastanawiamy się, co one znaczą i w jaki sposób działają, z czego są skonstruowane, ile kosztują i do czego moglibyśmy ich użyć. W obu wypadkach, stanowiących podstawowe działania podejmowane wobec obiektów materialnych, jawią się nam one jako coś, co po prostu jest, czego istnienia nie podajemy w wątpliwość, bo objawia się nam ono w sposób naoczny i namacalny. Ta pewność bycia przedmiotów sprawia, iż ich istnienie wydaje nam się nieproblematyczne, pytanie zaś o to, na czym ono polega, przynależy do kategorii problemów podejmowanych wówczas, gdy na chwilę opuszczamy codzienny świat, by oddać się autotelicznej refleksji bądź filozoficznym dysputom. Jeżeli jednak założymy, że zbiorowości, w których przebiega nasze życie, konstytuują nie tylko ludzie, ale też przedmioty, oraz że to, co ludzkie, jest możliwe dzięki temu, co materialne, to musimy również przyjąć, iż zrozumienie, jak istnieją przedmioty, stanowi klucz do odtworzenia tego, jak istnieje człowiek i zbiorowości ludzkie.

Jednym ze sposobów odpowiedzi na to pytanie jest przedstawiony niżej model przestrzeni życia przedmiotów oraz powiązana z nim koncepcja sposobów życia przedmiotów. Nie dostarczają one oczywiście wyczerpującej odpowiedzi na pytanie, jak istnieją obiekty materialne, ani tym bardziej nie wyjaśniają ostatecznie, jak istnieje człowiek i czym jest życie zbiorowości ludzkich, są jedynie przyczynkiem do zrozumienia, dlaczego niektóre $z$ dóbr materialnych są trwałe, inne zaś nie, dlaczego niektóre $z$ nich są obecne w naszych domach od

Adres do korespondencji: krajak@amu.edu.pl 
pokoleń, egzystencja zaś innych jest skrajnie krótkotrwała. Pytanie o powody trwałości obiektów materialnych wydaje się o tyle istotne, że to ten właśnie wymiar ich istnienia jest przez nas traktowany jako coś, co definiuje specyfikę obiektów materialnych i to on właśnie wytwarza nasze zaufanie do nich jako tych elementów życia społecznego i indywidualnego, które je stabilizują oraz sprawiają, iż jawi się nam ono jako obiektywne, niezmienne, przewidywalne. Ponieważ zaufanie to jest dzisiaj bardzo często podważane nie tylko przez przedmioty jednorazowe, „planowe zużycie” wpisane w obiekty materialne przez producentów, ale też przez kult tego, co nowe, oraz towarzyszące mu przemieszczanie się rzeczy z jednego kontekstu znaczeniowego i funkcjonalnego do innego, to pytanie o trwałość przedmiotów wydaje się szczególnie ważne.

Warto spróbować na nie odpowiedzieć, posługując się proponowanym tu modelem i pojęciami, nie tylko dlatego, że wpisany w nie sposób rozumienia trwałości dóbr materialnych ogromnie problematyzuje tę, wydawać by się mogło, oczywistą kategorię, ale też dlatego, że dwie najbardziej powszechne odpowiedzi na pytanie o powody trwałości dóbr materialnych wydają się mało satysfakcjonujące. Pierwsza $z$ nich czyni warunkiem trwałości przedmiotu materiał, z którego został on wykonany, bądź solidność jego wykonania, ale nie wyjaśnia, dlaczego kamienne pomniki czasami trwają zaledwie jeden dzień ${ }^{1}$, a obiekty wykonane $z$ tak kruchych materiałów jak porcelana czy papier są $\mathrm{w}$ stanie przetrwać stulecia. Druga z nich uzależnia trwałość przedmiotu od tego, w jaki sposób używa go człowiek (a więc od tego, czy używa go intensywnie, czy o niego dba, czy wykorzystuje go zgodnie z przeznaczeniem itd.), ale nie wyjaśnia ona, dlaczego niektóre z przedmiotów, zupełnie „zużyte”, trwają w ludzkich wspólnotach oraz dlaczego czasami te nietknięte przez ludzkie działanie są z nich usuwane.

\section{ŻYCIE PRZEDMIOTÓW}

Ponieważ obie odpowiedzi na pytanie o powody trwałości obiektów materialnych są mało satysfakcjonujące, chciałbym spróbować rozwiązać postawiony tu problem używając takich kategorii jak „życie przedmiotu”, „sposób życia przedmiotu” czy „przestrzeń życia przedmiotu”. Wykorzystanie ich jako środków udzielenia odpowiedzi i odnoszenie ich nie do ludzi, lecz do rzeczy, wydaje się istotne, gdyż zwraca uwagę na dwie kwestie. Po pierwsze, na to, iż przedmioty żyją, po drugie, iż różnią się między sobą nie tylko własnościami fizycznymi, funkcjami czy tym, w jaki sposób zostały wyprodukowane i jak są

1 Tak jak w wypadku pomnika buta, którym iracki dziennikarz Muntadar al-Zeidi rzucił w George'a Busha podczas konferencji prasowej w grudniu 2008 r. Postawiony miesiąc później monument przedstawiający gigantyczną kopię prawego buta, którym zaatakowano amerykańskiego prezydenta, przetrwał tylko jeden dzień, po czym władze w Bagdadzie kazały go usunąć. 
używane, ale też tym, w jaki sposób przebiega ich życie. Co więcej, to właśnie pojęcie sposobu życia przedmiotów, a więc specyficznego przebiegu egzystencji obiektów materialnych, pozwala lepiej uchwycić ich ulokowanie w życiu społecznym, zrozumieć ich rolę w jego formowaniu i reprodukcji, niż zezwalają na to tradycyjne sposoby ujmowania rzeczy, a więc analizowanie ich w kategoriach funkcjonalnych, symbolicznych, estetycznych czy technicznych.

Użycie kategorii „życie”/,żywe” w odniesieniu do rzeczy ponadto pozwala dostrzec, iż nie są one czymś zewnętrznym wobec porządku społecznego, czymś, co jest po prostu przez nas używane i czemu przypisujemy zupełnie odrębny status, ale raczej integralnym aspektem ludzkiego i społecznego świata. Elementem, który współtworzy zbiorowy ład i który jest konstytutywny dla tego, co społeczne, w takim samym stopniu jak konstytutywne są dlań działania aktorów ludzkich, wzorów kulturowych, interakcji, instytucji itd. (Latour 2005; Cassirer 2001). Używając pojęcia „życie przedmiotów” zwracamy więc uwagę na to, że obiekty materialne są podobne do ludzi w tym sensie, że i jedne, i drudzy wzajemnie się konstytuują i współokreślają (to, co ludzkie, jest możliwe dzięki temu, co materialne, i na odwrót; określone formy urzeczywistniania się człowieczeństwa pociągają za sobą odrębne formy materialności i na odwrót [Krajewski 2008]), ale też w tym sensie, że życie jednych i drugich zależne jest od zaistnienia relacji, która te obie strony ze sobą wiąże (Dant 2005; Abriszewski 2008).

W jakim sensie możemy mówić o życiu przedmiotów, co daje nam prawo używania tej kategorii w odniesieniu do obiektów, które zazwyczaj nazywamy martwymi i które zgodnie z zachodnimi systemami rozróżnień i klasyfikacji przeciwstawiamy żywym organizmom biologicznym? (Knappett 2005). Zanim odpowiemy na to pytanie, warto zwrócić uwagę na dwie kwestie. Po pierwsze, na to, że utrzymanie wyraźnego podziału między tym, co ludzkie, a tym, co nieludzkie, czyli żywe i martwe, jest dzisiaj bardzo trudne lub wręcz niemożliwe. Trudność ta wynika przede wszystkim $z$ faktu pojawienia się przedmiotów, które zachowują się jakby były żywe ${ }^{2}, z$ istnienia takich żywych organizmów, których egzystencja jest zależna od podtrzymujących ją maszyn ${ }^{3}$, a także $z$ tych dramatycznych i wywołujących dylematy moralne sytuacji, w których musimy zadecydować, czy człowiek już albo jeszcze żyje, czy też nie ${ }^{4}$. Utrzymanie silnej opozycji między żywym i martwym jest oczywiście społecznie doniosłe, ponie-

2 Chodzi tu przede wszystkim o urządzenia zrobotyzowane, ale też takie, które mają zdolność rejestrowania zmian zachodzących $\mathrm{w}$ środowisku i decydowania o tym, $\mathrm{w}$ jaki sposób na nie reagować (np. czytniki kart, kamery przemysłowe sprzężone z komputerami), czy też takie, które przybierają antropomorficzne kształty czy mówią ludzkim głosem.

3 Chodzi tu przede wszystkim o rosnącą protetyczność ludzkiego ciała, jego zależność od materialnych środków umożliwiających normalne funkcjonowanie (rozruszniki serca, mechaniczne repliki organów wewnętrznych, protezy, implanty itd.)

${ }^{4}$ Najlepszym przykładem są tutaj bardzo gorące spory i konflikt wokół z jednej strony prawa do dokonywania aborcji, a drugiej eutanazji. 
waż pociąga za sobą istnienie odrębnych zobowiązań moralnych i typów działań podejmowanych wobec tego, co przynależy do tych kategorii. Stanowi przy tym podstawę odpowiedzi na pytanie, kim jesteśmy jako gatunek. Jednocześnie jest dziś ogromnie kłopotliwe.

Drugą kwestią, która powinna pomóc w udzieleniu odpowiedzi na pytanie, w jakim sensie i czy w ogóle przedmiot żyje, jest wskazanie na dosyć rozbudowaną we współczesnej humanistyce tradycję traktowania przedmiotów tak, jakby były one żywe, a więc też podobne do ludzi i innych organizmów biologicznych.

Badania nad życiem przedmiotów wprowadziła do głównego nurtu nauk humanistycznych książka zredagowana przez Arjuna Appaduraia i zatytułowana The Social Life of Things (1986), a przede wszystkim zamieszczony w niej tekst Igora Kopytoffa Kulturowa biografia rzeczy (2004). Jedną z istotniejszych tez tego artykułu, poświęconego przede wszystkim procesom utowarowienia, było wskazanie, iż obiekty materialne, mimo fizycznej ciągłości i stabilności, zmieniają swoje role, funkcje oraz status kulturowy. Głównym źródłem tych transformacji są nakierowane na obiekty materialne działania jednostek, ale też przekształcanie się sposobów klasyfikowania obiektów materialnych obowiązujących w określonej wspólnocie. „Życie rzeczy” w ujęciu Kopytoffa to $\mathrm{w}$ istocie proces, $\mathrm{w}$ trakcie którego zmienia się kulturowy status przedmiotu, a więc następuje jego przemieszczanie się między różnymi systemami wymiany, włączanie bądź wyłączanie go $z$ nich.

Życiem przedmiotów zajmowali się również przedstawiciele różnych odmian studiów kulturowych, tworzyli imponujące monografie dotyczące pojedynczych kategorii dóbr, takich jak włoskie skutery (Hebdige 1988), walkman firmy Sony (Du Gay i in.1997), lalka Barbie (Rogers 2003) czy produkty firmy Nike (Goldman, Papson 1999) i Apple (Kahney 2005, 2006). Badaczy z tego kręgu interesowały przede wszystkim dobra konsumpcyjne, a analiza ich życia, czyli w tym przypadku procesów kulturowego produkowania, destruowania oraz rekonfigurowania znaczeń oraz konotacji przedmiotów, była środkiem prezentacji aktywnej roli konsumentów w tworzeniu masowo produkowanych obiektów, służyła także eksponowaniu faktu przesiąknięcia życia społecznego konfliktem i walkami wokół systemów reprezentacji określających, czym jest rzeczywistość. Życie przedmiotów, w tej perspektywie, to ich zmieniająca się pozycja w systemach reprezentacji definiujących granice realności, relacje władzy, spory i konflikty przenikające życie społeczne.

Innych autorów, takich jak Michael Thompson (1979), życie przedmiotów, a więc w tym wypadku kolejne uzyskiwane przez nie statusy kulturowe (rzeczy przejściowej, śmiecia, obiektu trwałego), interesowało jako perspektywa, dzięki której możemy rozumieć procesy wytwarzania i zużywania się wartości, ale która umożliwia też wyjaśnianie, dlaczego człowiek jest jedynym zwierzęciem, które najpierw pozbywa się obiektów materialnych, wyrzuca je i skazuje na śmietnik, by następnie, po znacznym upływie czasu, 
traktować resztki, odpady i śmieci jako cenne dobra kulturowe eksponowane $\mathrm{w}$ instytucjach chroniących materialne elementy dziedzictwa określonej społeczności.

Według jeszcze innych badaczy, na przykład Scotta Lasha i Celli Lury (2007), życie obiektu materialnego polega na krążeniu w globalnych sieciach, na przechodzeniu $z$ rąk do rąk i obrastaniu w nowe użytki, znaczenia i sensy, tworzone przez kolejnych użytkowników i instytucje. Badania życia przedmiotów polegają tym razem przede wszystkim na „podążaniu za nimi”, a więc są próbą rekonstrukcji dróg i kanałów ich krążenia, odtwarzaniem roli kolejnych kontekstów, w których są one ulokowane, w celu określenia tego, czym są, jak są używane i waloryzowane.

Refleksja nad „życiem przedmiotów” obecna jest też w tych odmianach socjologii i antropologii, które można nazwać relacyjnymi, a więc tych, które zajmują się analizą związków między ludźmi i przedmiotami oraz traktują je jako konstytutywne zarówno dla tego, czym są ludzie i rzeczy, jak i dla istnienia życia społecznego. W tych ujęciach przedmiot pojawia się jako obiekt, który jest żywy $\mathrm{w}$ tym sensie, że podziela $\mathrm{z}$ ludźmi pewne cechy, przede wszystkim zdolność do działania i czynienia różnicy (Gell 1998; Latour 2005), oraz w tym sensie, że przez same jednostki jest traktowany, jakby był wyposażony w osobowość, wolę, autonomię. Życie przedmiotu to przede wszystkim jego zdolność do uruchamiania działań ludzi, regulowania ich zachowań, umożliwiania i uniemożliwiania zrobienia czegoś człowiekowi, jest to więc $\mathrm{w}$ istocie uczestnictwo obiektu materialnego $\mathrm{w}$ życiu zbiorowości.

Pojęcie życia przedmiotu, a dokładniej historii życia przedmiotu, pojawia się również $\mathrm{w}$ archeologii, gdzie jest ono rozumiane jako zbiór procesów, $\mathrm{w}$ trakcie których obiekt interaguje z innymi rzeczami i ludźmi, procesów rozpoczynających się wytworzeniem przedmiotu, a kończących się pozbyciem się go przez jednostkę lub wspólnotę (Schiffer 1999, s. 22-23). Istotne jest też to, że każdy $z$ procesów tworzących historię życia przedmiotu modyfikuje potencje obiektu materialnego, jego zdolność do interagowania $z$ ludźmi, a więc wpływa też na przebieg kolejnych działań, w których określona rzecz uczestniczy, i w rezultacie prowadzi do wyczerpania jego wartości.

Warto zaznaczyć, iż kategoria „życie przedmiotów” była równie często używana jak krytykowana, a głównym zarzutem, który kierowano wobec stosujących ją badaczy, było zawarte w niej niebezpieczeństwo antropomorfizacji przedmiotów, zacierające ich swoistość, ale też pociągające za sobą ryzykowne konsekwencje, takie jak identyczność zobowiązań moralnych wobec ludzi i przedmiotów (Domańska 2006) czy zrównanie istotności więzi łączących ze sobą jednostki z tymi, które spajają je z obiektami materialnymi.

Niebezpieczeństwa te, moim zdaniem, można ominąć przyjmując, iż kategoria „żywe” używana w kontekście społecznym oznacza, iż coś (człowiek, zwierzę, przedmiot) jest aktywnym aspektem relacji konstytuujących 
zbiorowości ${ }^{5}$, a więc że współokreśla, czym są inne elementy tworzące całości społeczne, wiąże je ze sobą, prowadzi do ich stabilizacji i prowokuje ich zmianę. Kategoria „żywe” używana w powyższym sensie opiera się więc na założeniu, że podstawowe znaczenie dla tworzenia, trwania w czasie i zmian zbiorowości mają relacje sprzęgające ze sobą rozmaite (ludzkie i nieludzkie) elementy i to właśnie te relacje zarówno określają, z czym mamy do czynienia, jak i wyznaczają status, role, funkcje, sposoby działania tych elementów w obrębie całości (Emirbayer 1997; Abriszewski 2008).

Kategoria „żywe” w przyjmowanym tu sensie pozwala wyjaśniać, dlaczego czasami żywych w sensie biologicznym ludzi traktujemy jak martwych i dlaczego oni sami, pomimo tego, że nic nie zagraża sprawnemu funkcjonowaniu ich organizmów, czują się tak, jakby nie żyli, a także to, dlaczego niektóre przedmioty są przez nas traktowane jakby były żywe i podobne do organizmów biologicznych czy wręcz ludzi (Dant 2005; Gell 1998). Proponowany sposób rozumienia tego, co ożywione, umożliwia też zrozumienie charakterystycznego dla zachodnich społeczeństw fetyszyzowania nieśmiertelności, które przejawia się w towarzyszących nam od XIX wieku praktykach określanych mianem statuomanii (Hobsbawm, Ranger 2008) czy muzealizacji (Lübbe 1988).

Kategoria „żywe” w proponowanym tu rozumieniu ma więc sens podobny do tego, w jakim jej używamy, gdy mówimy o żywej tradycji, kulturze, wspomnieniach, uczuciu, albo gdy wyjaśniając kulturowy status obrazów i innych reprezentacji, nazywamy je żywymi, dlatego że wywołują nasze reakcje (Freedberg 2005) albo „czegoś od nas chcą” (Mitchell 2005). Bycie żywym oznacza więc aktywny udział w konstytuowaniu zbiorowości, w kształtowaniu statusu i funkcji składających się na nie elementów, wpływanie na to, w jaki sposób one działają i czy działają.

Możemy więc przyjąć, iż przedmiot żyje, jeżeli w obrębie określonej zbiorowości jest „po coś”, a to „po coś” oznacza przede wszystkim możliwość albo konieczność zrobienia z nim czegoś, za jego pomoca, przy udziale albo ze względu na niego czy pod jego wpływem. Przedmioty żyją, jeżeli wysuwają wobec nas skuteczne roszczenie do tego, by coś z nimi zrobić - skuteczne, a więc takie, które wiąże się z odpowiedzią na nie (Gibson 1977; Mitchell 2005). Przedmiot żyje więc wówczas, gdy wyzwala działanie, umożliwia jego przeprowadzenie, albo uniemożliwia zrealizowanie czegoś. Przedmiot przestaje żyć, gdy staje się obojętnym aspektem naszych działań, gdy niczego od nas nie żąda ani niczego nam nie oferuje i nie zabrania, nie wpływa na nic, co konstytuuje daną zbiorowość. Warto zaznaczyć, iż przedmioty są żywe w sposób niezależny od ich fizycznego istnienia i stanu. Żywym przedmiotem jest z pewnością również

${ }^{5}$ Zbiorowości rozumiem tu w taki sposób, jaki proponuje Bruno Latour, a więc jako „powiązanie, zebranie razem rzeczy i ludzi, czynników ludzkich (humans) i pozaludzkich (nonhumans)" (zob. Abriszewski 2009, s. 213). 
obiekt, którego już albo jeszcze nie ma, ale którego obecność we wspomnieniach lub marzeniach jednostki powoduje, iż wpływa on na jej sposób działania i myślenia.

Tym, co ożywia obiekty materialne, jest działanie ludzkie, które zostaje na nie skierowane, ale też takie, które prowokuje sam przedmiot. Jednocześnie — i to wydaje się szczególnie istotne i warte podkreślenia - człowiek może działać, jeżeli przedmiot na to zezwala (Gell, 1998), a więc precyzyjne rozróżnienie między podmiotem a przedmiotem działania jest równie trudne do przeprowadzenia, jak rozróżnienie między tym, kto sprawuje władzę, a tym, kto jej podlega w stosunkach panowania (Ziółkowski 1994). Zdolność do działania nie jest więc, jak powiedziałby Alfred Gell, cechą aktora (człowieka bądź przedmiotu), ale raczej własnością relacji, w której on uczestniczy i którą współtworzy. Zarówno rzeczy, jak i ludzie dysponują potencjami, których uaktywnienie i wykorzystanie w konkretnej interakcji może nastąpić, jeżeli zezwalają na to partnerzy, a więc zarówno ludzie, jak i obiekty materialne. Potencjalności te to przede wszystkim własności interagujących (cechy biologiczne, fizyczne, chemiczne, kształt, wielkość, a w przypadku ludzi również wiedza, kompetencje, sprawność $\mathrm{w}$ posługiwaniu się własnym ciałem itd.), ich uaktywnianie zaś w relacjach łączących ludzi i przedmioty zachodzi w obu kierunkach. Człowiek ujawnia poprzez swoje działanie potencje drzemiące w rzeczach, one zaś pomagają rozpoznawać ludziom te tkwiące $\mathrm{w}$ nich samych, są więc one źródłem rozpoznania ludzkich możliwości i ograniczeń, a więc pomagają $\mathrm{w}$ samopoznaniu, rozwoju samoświadomości (Cassirer 2001; Campbell 2006; Krajewski 2008).

Ludzie i rzeczy to nie tylko powiązani ze sobą aktorzy, wzajemnie wyzwalający tkwiące $\mathrm{w}$ nich potencje, ale to również, jak powiedziałby Schiffer compound interactors, działające całości, interagujące $z$ innymi oraz z zewnętrznym środowiskiem, odpowiadające także na procesy czysto chemiczne i fizyczne, które zachodzą bez ich udziału i wpływu. Takim złożonym interagującym jest każdy $z$ nas, gdy używa przedmiotów, a więc na przykład człowiek spożywający posiłek. Czynność ta jest możliwa do wykonania nie przez jednostkę, ale przez złożoną całość, na którą składa się ten, który je, ale też obiekty, które w spożywaniu posiłku pośredniczą i działanie to umożliwiają. Dla zewnętrznego obserwatora jedzący i używane przez niego obiekty materialne tworzą całość pozwalającą temu, kto ją obserwuje, zrozumieć to, co widzi, poddać ocenie, określić możliwe skutki realizowanej $\mathrm{w}$ ten sposób czynności. Złożeni interagujący są w stanie działać, jeżeli zezwalają na to zarówno składające się na nich ludzkie, jak i nieludzkie elementy. Proponowany tu sposób rozumienia kategorii „życie przedmiotów” pozwala więc dostrzec, iż życie społeczne to ogromnie skomplikowana, wielowymiarowa sieć relacji, spajająca ze sobą ludzi, rzeczy oraz zewnętrzne wobec nich zjawiska, stanowiące aspekty środowiska, w którym owe przedmioty funkcjonują. 


\section{PRZESTRZEŃ ŻYCIA PRZEDMIOTU}

Wyjaśniliśmy, w jaki sposób rozumiemy kategorię „życie przedmiotu”, spróbujmy teraz określić, czym są sposoby życia dóbr materialnych. Stosując tę kategorię $\mathrm{W}$ odniesieniu do przedmiotów mam na myśli przede wszystkim tryb, $\mathrm{w}$ jakim przebiega i w jakiej formie realizuje się udział rzeczy w kształtowaniu relacji ustanawiających zbiorowości. Sposób życia przedmiotów uwidacznia się w takich aspektach jak: trwałość uczestnictwa obiektu w konstytuowaniu relacji tworzących zbiorowość, stopień stabilności jego statusu w tych stosunkach, jego mono- lub wielorelacyjność, a więc to, czy uczestniczy on tylko w jednym, czy też w wielu związkach spajających wspólnotę. Tym, co różnicuje te aspekty, jest przede wszystkim ulokowanie i przemieszczanie się określonych obiektów w przestrzeni życia przedmiotów. Przestrzeń tę konstytuują dwa podstawowe wymiary.

Pierwszy z nich wymusza charakter relacji ustanawianych, podtrzymywanych lub destruowanych dzięki przedmiotom i przez nie same. Generalnie relacje te reprezentują typy rozciągające się od bieguna stosunków czysto technicznych do bieguna, na którym znajdują się te o charakterze komunikacyjnym. $Z$ jednej strony przedmioty mogą więc $w$ relacjach łączących je $z$ ludźmi występować jako narzędzia, których przeznaczeniem jest przekształcanie rzeczywistości, uzyskiwanie dostępu do niej (mówimy wówczas o przyrządach) czy wpływanie na innych, z drugiej mogą być środkami, za pomocą których komunikujemy się ze sobą oraz $z$ innymi, przekazując znaczenia, samookreślając, definiując innym swoje cele oraz statusy, prowadząc dialog z samym sobą ${ }^{6}$. Do pierwszej kategorii należą sztućce, łopaty i piły, pojazdy, ale również telefony i telewizory, bo nie tyle one komunikują, ile raczej są narzędziami komunikacji, pozwalają na uzyskanie dostępu do informacji. Do drugiej kategorii należą ubrania, biżuteria, symbole religijne i narodowe, pomniki itd., a więc obiekty, które określamy mianem semioforów (Pomian 2006), funkcjoznaków czy symboli przedmiotowych. Warto podkreślić, iż relacje techniczne i komunikacyjne to nie rozłączne klasy stosunków, ale ich typy, między którymi istnieje ogromna liczba związków pośrednich. Ten sam przedmiot może być obecny jednocześnie $\mathrm{w}$ relacjach technicznych i komunikacyjnych, może też $\mathrm{w}$ różnych fazach swego życia przemieszczać się między nimi. Przykładem tej pierwszej sytuacji jest ubranie, które służy realizacji funkcji technicznych (chroni przez zimnem lub urazami), ale pełni też funkcje komunikacyjne (wskazuje na status jednostki i jej tożsamość). Przykładem tej drugiej sytuacji jest zamiana czysto użytkowego narzędzia, na przykład naparstka, w pamiątkę po bliskiej osobie

\footnotetext{
${ }^{6}$ Mówiąc o komunikacji mam na myśli przede wszystkim procesy przekazywania i odbierania znaczeń o charakterze symbolicznym, a więc takich, w których między przedmiotem a tym, do czego się on odnosi, istnieje konwencjonalny i ustanowiony przez człowieka związek.
} 
bądź obiekt muzealny, a więc w przedmioty obecne w relacjach komunikacyjnych, służące przenoszeniu informacji.

Drugim wymiarem wyznaczającym interesującą nas tu przestrzeń życia przedmiotu jest specyfika relacji zachodzącej między obiektem materialnym a ciałem człowieka, a dokładniej to, w jaki sposób obiekt dany jest doświadczeniu zmysłowemu jednostki. Tego typu stosunki przedmiot-ciało ludzkie można ułożyć na linii biegnącej od tych, w których przedmioty są doświadczane wszystkimi zmysłami i w których możemy nimi manipulować, przez te, w których rzecz jest dostępna tylko naszemu wzrokowi, ale już nie dostarcza doświadczeń taktylnych, aż do tych, w których obiekt uczestniczy w naszych działaniach, ale nie jest przez nas doświadczany zmysłowo, odczuwamy jedynie skutki jego obecności. Przedmioty różnią się więc między sobą nie tylko tym, czemu służą, ale również tym, czy są dostępne naszemu doświadczeniu zmysłowemu, czy też nie. Niektórych obiektów materialnych umożliwiających moje działania doświadczam za pomocą zmysłów, dotykam ich i widzę je, inne są temu doświadczeniu niedostępne, ale wpływają na podejmowane przeze mnie działania. Tę drugą kategorię stanowią przede wszystkim mechanizmy we wnętrzach używanych przez nas narzędzi i maszyn, elementy infrastruktury dostarczającej do naszych domów energię elektryczną, wodę, gaz, powietrze, systemy ogrzewające nasze mieszkania. Wpływają one na nasze działania i umożliwiają je, ale większość z nich nie jest przez nas percypowana, są one dostępne jedynie doświadczeniu ekspertów projektujących je i wytwarzających, utrzymujących w stanie gotowości oraz naprawiających, gdy przestają działać. Do tej pierwszej grupy należą przede wszystkim obiekty konstytuujące naszą codzienność, a więc te, którymi manipulujemy realizując swoje zamiary, ale też te, które znajdują się $\mathrm{w}$ polu naszego widzenia, które musimy wziąć pod uwagę, gdy planujemy działanie. Oczywiście, podobnie jak w wypadku pierwszego z wymiarów nakreślających przestrzeń życia przedmiotów, poszczególne rzeczy mogą przemieszczać się między biegunami wyznaczonymi przez dostępność i niedostępność doświadczeniu zmysłowemu. Dzieje się tak na przykład w przypadku przedmiotów, które początkowo były przez nas percypowane i poddawane namysłowi, a które stają się „niewidzialne” wraz z ich unawykowieniem, wdrukowaniem $w$ nie naszych codziennych schematów postępowania (Kauffman 2004; Edensor 2005; Schmidt, Skowrońska 2008). Swoje położenie na tym drugim wymiarze zmieniają również te obiekty, które nie są przez nas zmysłowo doświadczane i które są temu doświadczeniu niedostępne, ale które stają się widzialne za sprawą awarii czy usterek, albo wówczas gdy na przykład zostają wyeksponowane jako obiekty muzealne czy stają się przedmiotem pożądania kolekcjonerów bądź pasjonatów zajmujących się ewoluowaniem kultury materialnej.

Oba wymiary konstytuujące przestrzeń życia przedmiotu są ze sobą powiązane i tworzą przestrzeń życia przedmiotu, określającą status obiektu materialnego $\mathrm{w}$ procesach ustanawiania, podtrzymywania, przekształcania i destrukcji 
relacji - procesach, dzięki którym możliwe jest istnienie zbiorowości wiążących ze sobą rzeczy i ludzi. Sposób życia przedmiotu określony jest przez jego pierwotne ulokowanie $\mathrm{w}$ tej przestrzeni, ale również przez to, $\mathrm{w}$ jaki sposób się w niej przemieszcza. Mówiąc jeszcze inaczej, z jednej strony odmienność tego, jak przedmiot żyje, jest wyznaczona przez to, czy został on zaprojektowany jako środek komunikacji, czy też jako narzędzie realizacji celów czysto technicznych, a także przez to, czy jest dostępny czy niedostępny ludzkiemu doświadczeniu zmysłowemu, $z$ drugiej zaś strony to, $w$ jaki sposób przedmiot żyje, wyznacza jego przesuwanie się między omawianymi wymiarami - przemieszczanie, które następuje na skutek zmian relacji łączących ów przedmiot ze zbiorowością, w obrębie której został ulokowany. Przestrzeń życia przedmiotu można zilustrować w sposób następujący (zob. rysunek 1).

Przestrzeń życia przedmiotu

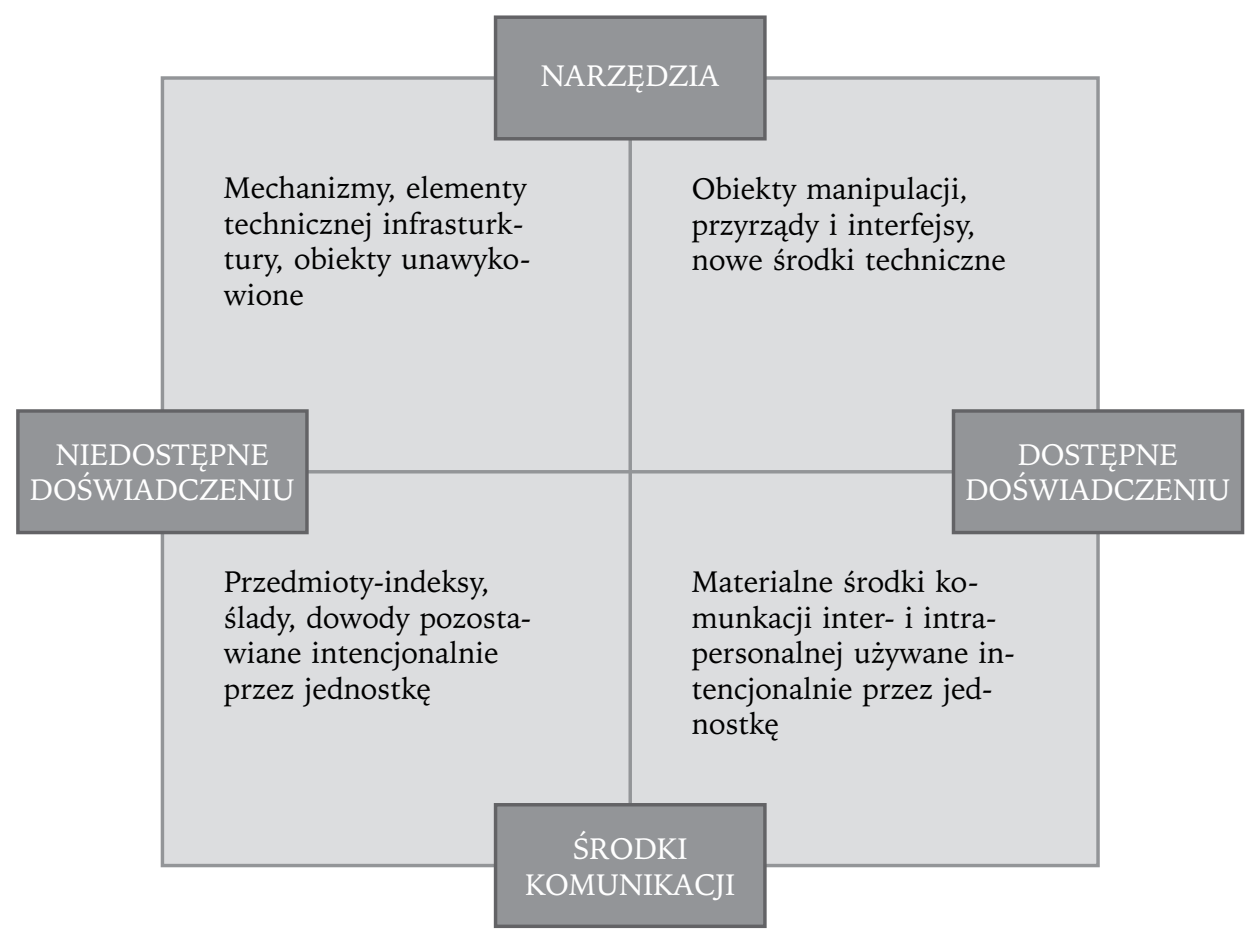

TRWAŁOŚĆ DÓBR MATERIALNYCH

Po przedstawieniu podstawowych dla proponowanej koncepcji pojęć chciałbym przejść do odpowiedzi na pytanie postawione na wstępie - o powody, które decydują o tym, że pewne przedmioty są trwałe, inne zaś nie, traktując jednocześnie tę kategorię, a więc trw a o ść r z e c zy jako najważniejszy aspekt 
sposobu ich życia. W jaki sposób tę kategorię rozumiem. Przede wszystkim jako czas, w jakim obiekt jest obecny w relacjach konstytuujących określoną zbiorowość, ale też jako niezmienność jego pozycji w przestrzeni życia przedmiotów, a więc jako jego stabilność. Przedmiot trwały to zatem taki obiekt, który jest $z$ nami od zawsze, ale też taki, którego role, funkcje, sposób, w jaki go używamy, nie ulegają zmianie. Takie rozumienie trwałości rzeczy dużo lepiej niż utożsamienie tej cechy z fizycznymi własnościami dóbr materialnych odzwierciedla drzemiące $\mathrm{w}$ nich stabilizujące potencje oraz ich zdolność do bycia osnową, na której zostają oplecione działania jednostek, ich nawyki, przyzwyczajenia, interakcje z innymi, a więc wszystkie te elementy, które współtworzą to, co społeczne. W tym sensie trwałym przedmiotem może być zdjęcie przedstawiające istotną dla mojej tożsamości osobę, niezbędne dla autoryzowania mojej biografii, nietrwałym obiektem zaś może okazać się przedmiot wykonany z niezniszczalnego materiału, którego jednostka się pozbywa, bo dyskredytuje on ją jako osobę niemodną, o guście nieodpowiednim dla jej statusu itd.

$\mathrm{Z}$ czego wynika więc trwałość przedmiotu? Co sprawia, że w naszych domach istnieją przedmioty, które są w nich od zawsze, i takie, które pojawiają się tylko na chwilę, by równie gwałtownie zniknąć?

Jak się wydaje, trwałymi obiektami są te rzeczy, które zajmują skrajne, brzegowe pozycje w przestrzeni życia przedmiotów, nietrwałymi stają się zaś te, które zbliżają się ku jej środkowi. Mówiąc jeszcze inaczej, obiekty trwałe to, po pierwsze, proste narzędzia, po drugie, przedmioty, których jedyną funkcją jest komunikowanie, po trzecie te, które komunikuja, ale w sposób przez nas niezamierzony, a także te, po czwarte, które pełniąc funkcje czysto instrumentalne pozostają poza naszym doświadczeniem zmysłowym, a nam dane są tylko skutki, które one wywołują. Warto zwrócić uwagę na to, że trwałość przedmiotu w trakcie jego życia w obrębie określonej zbiorowości może się zmieniać, a więc — podobnie jak inne cechy — nie jest ona jego istotową własnością, ale raczej czymś, co przedmiot ów uzyskuje w aktualnie oplatających go relacjach. Przedmioty nietrwałe mogą stać się trwałymi (tak jak dzieje się na przykład, gdy część garderoby jednostki staje się tym elementem jej własności, który najpełniej ją definiuje, a więc jej „ulubionym ciuchem”), ale też na odwrót (na przykład gdy „ulubiony ciuch” zostaje zdeprecjonowany przez osobę istotną dla danej jednostki, staje się przez to wieloznaczny i musi ona coś z nim zrobić, by podtrzymać swoją tożsamość bądź status). Generalnie jednak o tym, że przedmiot staje się trwały, decyduje jego przesuwanie się ku zewnętrznym krańcom przestrzeni życia przedmiotów, a więc tam, gdzie znajdują się obiekty powiązane ze zbiorowością jednoznacznymi relacjami, a więc też takie, które ją stabilizują.

Poniższy rysunek obrazuje, w jaki sposób obiekty trwałe i nietrwałe są osadzone w przestrzeni życia przedmiotów, a także jaki kierunek przemieszczania się obiektów materialnych w jej obrębie powoduje, iż stają się trwałe.

Obiekty trwałe to na przykład kuchenne przybory (a więc unawykowione narzędzia), których używam, by przygotować sobie śniadanie - czajnik, nóż, 
Trwałość przedmiotu

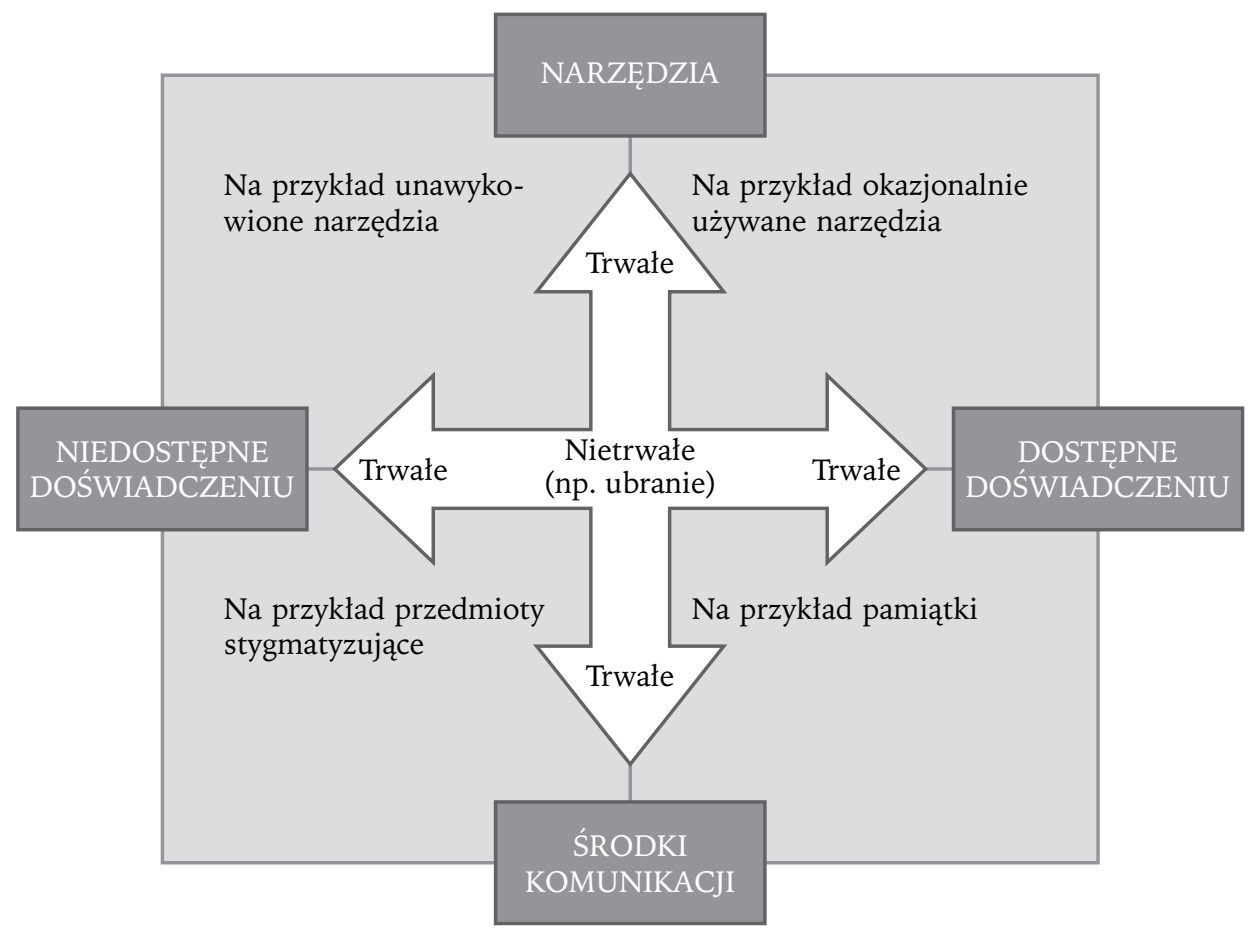

deska do krojenia, talerz, sztućce, stół, kubek itd. Są one prostymi przyrządami, ale też tak bardzo splecionymi z moimi codziennymi czynnościami, że stają się w takim stopniu oczywiste, że aż „niewidzialne” i dzięki temu w sposób automatyczny uruchamiają moje nawykowe działania osadzone w stabilnym punkcie mojej czasoprzestrzeni. Do tej samej kategorii trwałych obiektów należą też elementy energetycznej infrastruktury mojego domu (rury, przewody, kanały wentylacyjne itd.), których nie doświadczam bezpośrednio, nie poddaję ich refleksji, ale jednocześnie dzięki ich sprawnemu funkcjonowaniu moja codzienność, relacja $z$ innymi obiektami mogą zostać podtrzymane, a cała zbiorowość, na którą składają się ludzie i przedmioty, może trwać w czasie. Inną kategorię trwałych przedmiotów stanowią obiekty, których używam tylko i wyłącznie po to, by coś symbolicznie zakomunikować i które jednocześnie poddaję namysłowi. Takimi obiektami są z pewnością rodzinne pamiątki - stanowią one przedmioty sakralne, które nawet jeśli kiedyś były narzędziami, dziś służą wyłącznie aktualizowaniu relacji z tymi, którzy odeszli, uobecnianiu nie istniejących już jednostek lub sytuacji, traktowanych jako konstytutywne dla tożsamości. Trwałymi obiektami są również narzędzia, których obecności jestem świadom, których w pełni świadomie doświadczam, ale które nie zostały unawykowione, ale też nie pełnią żadnych funkcji ko- 
munikacyjnych, lecz jedynie służą realizacji zadań technicznych (np. śrubokręt czy wiertarka, których używam rzadko i niewprawnie, za każdym razem ucząc się zgrywania z nimi mojego ciała). Ich trwałość jest przede wszystkim funkcją tego, że chociaż są one przydatne, to funkcjonują jednocześnie za kulisami, skąd są wydobywane tylko okazjonalnie. Ich nieobecność w codziennych zmaganiach $z$ rzeczywistością sprawia, iż dane są nam $\mathrm{w}$ sposób jednowymiarowy, wyłącznie jako narzędzia. Trwałe obiekty to również przedmioty, które mnie dyskredytują i podważają moje prawo do bycia tym, kim jestem, ale których znaczeń nie jestem świadom, tak jak w przypadku obiektów, do których przywykłem, a które jednocześnie stały się niemodne albo są niezgodne $z$ moim aktualnym społecznym statusem. Są one trwałe w tym sensie, że chociaż komunikują, to jednocześnie dla jednostki, która się nimi posługuje, ich znaczenia są zredukowane tylko do tych, których jest ona świadoma, nie zaś tych, które docierają do zewnętrznych obserwatorów. Relacje łączące tego typu obiekty ze zbiorowością (i samą jednostka) są więc jednoznaczne, bo osoba, która ich używa, nie zdaje sobie sprawy z tego, że przedmioty te komunikują przeciwko niej. Ulubiony fotel służący oglądaniu telewizji, bez którego nie wyobrażam sobie wieczornego relaksu i który konotuje domowość i prywatność, dla osoby, która mnie odwiedza, może być obrzydliwym, starym meblem, naznaczonym silnie długotrwałym użytkowaniem i definiującym mnie jako osobę niezdolną do sprawowania pełnej kontroli nad swoim życiem. Warto też zauważyć, że gdy jednostka staje się świadoma tego, iż przedmiot komunikuje przeciwko jej tożsamości i podważa prawo do określonych identyfikacji, relacje łączące obiekt ze zbiorowością stają się wieloznaczne, a przedmiot ów sam przestaje ją stabilizować i wymusza zmiany.

Nietrwałe obiekty to $z$ kolei przede wszystkim te przedmioty, które są wieloznaczne, a więc lokują się w centralnych rejonach przestrzeni życia przedmiotów. Ich egzystencja jest bardzo intensywna, bo połączone są bardzo różnorodnymi typami relacji ze zbiorowością, a tym samym są bardzo podatne na zmiany. Ich nietrwałość spowodowana jest przede wszystkim tym, że uczestniczą one w ustanawianiu kilku relacji jednocześnie, a także tym, że są w zróżnicowany sposób dostępne jednostkowemu doświadczeniu. Na przykład ubranie jest jednocześnie narzędziem i środkiem komunikacji zarówno z samym sobą, jak i z innymi jednostkami, pewne jego aspekty są stale monitorowane przez jednostkę, ale niektórych nie jest ona świadoma (na przykład wrażeń, które owo ubranie wywiera na innych). Oznacza to, że z konieczności ubrania zmieniają się zarówno wówczas gdy przestają pełnić swoje techniczne funkcje (np. zużywając się w trakcie noszenia), jak i wówczas gdy wyczerpują się ich, oczekiwane przez jednostkę, potencje komunikacyjne (a więc na przykład gdy zmienia się jednostkowa tożsamość bądź status, które one komunikowały, a także gdy zmieniają się zewnętrzne kody określające ich znaczenia). Ubranie przemieszcza się też między „widzialnością” i „niewi- 
dzialnością", jednostka nieustannie je monitoruje, ale też jego noszenie ulega unawykowieniu. $Z$ konieczności dla większości z nas jest ono obiektem nietrwałym.

W podsumowaniu można stwierdzić, iż trwałość przedmiotu, stanowiąca jeden $z$ najbardziej konstytutywnych aspektów jego sposobu życia, nie jest zdeterminowana przez jakiekolwiek cechy fizyczne, ale raczej przez relacje, w które on wchodzi w określonej zbiorowości, zarówno te $z$ innymi obiektami materialnymi, jak i te z ludźmi. Ubrania, których użyliśmy jako przykładu obiektu nietrwałego, dla osób, które traktują je wyłącznie jako ochronę przed zimnem i dla których nie są ważne opinie innych na ich temat, będą z pewności rzeczami trwałymi, połączonymi z właścicielem stabilnymi i jednoznacznymi relacjami.

Warto zwrócić uwagę również na inne kwestie związane $z$ interesującym nas tu aspektem różnicującym sposoby życia przedmiotów, a więc $z$ ich trwałością.

Po pierwsze, na to, że obiekty materialne należące do tej samej klasy rzeczy (a więc stoły, krzesła, spodnie, zdjęcia, telewizory itd.) mogą w różnych zbiorowościach (a więc $\mathrm{w}$ tym wypadku $\mathrm{w}$ odrębnych przestrzeniach domowych) zostać odmiennie usytuowane $\mathrm{w}$ przestrzeni życia przedmiotu, a tym samym być mniej lub bardziej trwałym elementem relacji konstytuujących te zbiorowości. Na przykład sieci elektryczne z konieczności zajmują inną pozycję $\mathrm{w}$ zbiorowościach, w których funkcjonują technicy zajmujący się ich zakładaniem, osoby kradnące prąd i te, które mają do niego legalny dostęp. Inną pozycję $\mathrm{w}$ przestrzeni życia przedmiotu zajmuje samochód zawodowego, a inną i niedzielnego kierowcy, podobnie jak ubranie tych, którzy wykonują prace „na fasadzie” różnych instytucji, reprezentując je, i tych, którzy działają w kulisach. Oznacza to tylko tyle, że trwałość przedmiotów nie jest ich immanentną cechą, ale raczej sytuacyjną własnością, której natężenie określa specyfika relacji tworzących określoną zbiorowość i usytuowanie obiektów $\mathrm{w}$ ich obrębie.

Po drugie, każdy konkretny obiekt materialny (a więc stół, krzesło, spodnie, fotografia albo telewizor) w trakcie swego życia zmienia pozycję zajmowaną w przestrzeni życia przedmiotów, ale zmiany te mają odmienne konsekwencje dla istnienia zbiorowości, które obiekty te współkonstytuują. Obiekty, które nazwaliśmy trwałymi, a więc te, które są jednoznaczne mimo zmiany pozycji, co zazwyczaj prowadzi do przebudowania zbiorowości i konstytuujących ją relacji. Dzieje się tak wówczas, gdy czysto techniczny obiekt używany przez jednostkę przekształca się w źródło jej dyskredytacji. Pociąga to za sobą nie tylko zmianę jego pozycji w przestrzeni życia przedmiotów (narzędzie staje się środkiem komunikacji), ale też konieczną przebudowę całej zbiorowości, bo skutkuje zmianą sposobu myślenia jednostki o niej samej. W przypadku przedmiotów nietrwałych zmiana ich pozycji w relacjach konstytuujących zbiorowość nie powoduje przekształceń tych związków, ale raczej i najczęściej zastąpienie 
ich innymi obiektami, bardziej adekwatnie zaspokajającymi aktualne potrzeby i oczekiwania jednostki.

Do czego może być użyteczna powyższa koncepcja? Na jakie aspekty życia społecznego zwraca uwagę? Czy czyni czytelniejszymi nasze relacje z przedmiotami?

Po pierwsze, koncepcja ta pozwala dostrzec, iż relacje z obiektami materialnymi, w które wchodzi jednostka, są konstytutywne dla tego, kim ona jest, i to nie tylko w sensie akceptowanych przez nią wartości i postaw przejawiających się w jej stylach życia, ale na bardziej podstawowym poziomie, a mianowicie codziennych działań, poprzez które adaptuje się ona do rzeczywistości. Jednostka jest tożsama ze zbiorowością, którą sama buduje, jest więc złożonym interagującym, konstytuowanym przez relacje, w które wchodzi, i określonym przez ich specyfikę. Być człowiekiem to wytwarzać przedmioty, używać ich, niszczyć je i myśleć o nich, ale też być przez nie tworzonym i współokreślanym. Utrzymywanie silnej opozycji między tym, co ludzkie, a tym, co nieludzkie, żywe i martwe, organiczne i materialne, pozwala nam, co prawda, na budowanie solidnych podstaw naszej gatunkowej tożsamości i definiuje nas jako tych, którzy mają prawo do czynienia świata sobie poddanym, ale uniemożliwia również dostrzeżenie tego, iż bycie człowiekiem to bycie zależne od przedmiotów i możliwe tylko przy ich udziale.

Po drugie, przedstawiony model przestrzeni życia przedmiotów pozwala dostrzec, iż obiekty materialne są nie tylko nośnikami znaczeń czy reprezentacjami społecznych różnic, ale również rzeczami inicjującymi działania, uruchamiającymi nawyki i aktualizującymi codzienne schematy postępowania, a także zwykłymi narzędziami. To, czym jest przedmiot, jest określone przez charakter relacji, które wiążą go $z$ innymi elementami tworzącymi określoną zbiorowość. Oczywiście, warto pamiętać, iż jednostka uczestniczy w różnych typach zbiorowości, na które składają się ludzie i rzeczy, a także w zbiorowościach, które składają się z compound interactors i które działają $z$ wykorzystaniem rozbudowanej infrastruktury materialnej. Te ostatnie, megazbiorowości, najczęściej określane mianem grup społecznych albo społeczeństw, stanowią istotny czynnik określający sposób konstruowania przez jednostkę własnej zbiorowości, a więc najbardziej intymnej, najbliższej jej doświadczeniu sieci łączącej ludzi i rzeczy.

Po trzecie, model ten wyjaśnia również, dlaczego strata przedmiotów, ich psucie się, gubienie ich czy destrukcja często wywołuje gwałtowne, emocjonalne reakcje jednostki, niewspółmierne do wartości tego, co zostało utracone. Poczucie straty, często boleśnie odczuwane, jest wywoływane przez obniżenie poziomu poczucia bezpieczeństwa wynikające $z$ zachwiania zestalonych rytmów funkcjonowania zbiorowości i samej jednostki oraz z konieczności bu- 
dowania nowych sieci oplatających ludzi i obiekty. Jak się wydaje, przy użyciu proponowanej tu koncepcji można próbować odpowiedzieć na pytanie, dlaczego jednostki wyrzucają przedmioty materialne również wtedy, gdy są one całkowicie sprawne pod względem technicznym i funkcjonalnym. Ich usuwanie jest konsekwencją przesuwania się $\mathrm{w}$ przestrzeni życia przedmiotu w kierunku obiektów nietrwałych, a więc takich, które są spojone ze zbiorowością niejednoznacznymi relacjami, ale też pojawia się wówczas, gdy zbiorowość ulega przebudowie.

Po czwarte, model ten pozwala również zdefiniować, na czym polegają współczesne problemy z przedmiotami - przede wszystkim na tym, że bardzo wiele obiektów przesuwa się w kierunku środka przestrzeni życia obiektów, a więc żyje bardzo intensywnie, a co za tym idzie krótko, co z kolei powoduje destabilizację relacji konstytuujących określoną zbiorowość. To przesuwanie ich w określonym wyżej kierunku ma źródło przede wszystkim w tym, że każdy przedmiot - jako dobro konsumpcyjne i towar - musi zostać przez kogoś wybrany, a to wymaga uczynienia go widzialnym przedmiotem naszego doświadczenia i refleksji, a tym samym charakterystycznej dla rzeczy oczywistości. Wpływ kultury promocyjnej, a więc tej najważniejszej funkcji rozwiniętego systemu kapitalistycznego, polega przede wszystkim na próbie wprawienia przedmiotów $\mathrm{w}$ ruch, na ich problematyzowaniu, na czynieniu ich wieloznacznymi, bo to pociąga za sobą konieczność ich wymieniania, by utrzymać stabilność zbiorowości, w których przebiega nasze życie, i podstawowych punktów odniesienia dla naszej tożsamości. Nietrwałość obiektów materialnych - stanowiąca jedną z najważniejszych cech współczesnej kondycji człowieka, odpowiedzialna za trudność z udzieleniem odpowiedzi na pytanie, co to znaczy być człowiekiem - wynika również ze zróżnicowania społeczeństw. Dyferencjacja oznacza bowiem, iż te same rzeczy zostają przez poszczególne jednostki inaczej ulokowane w przestrzeni życia przedmiotów, co zmusza nas do nieustannego negocjowania $z$ innymi tego, jakie typy relacji łączące nas z obiektami materialnymi są właściwe, normalne, obowiązujące.

Po piąte, proponowany tu model wyjaśniający trwałość przedmiotów pozwala zrozumieć, dlaczego bardzo wiele obiektów materialnych komunikujących „przeciwko nam” i przenoszących nieakceptowane przez nas znaczenia i ideologie (np. komunistyczne pomniki i materialne pozostałości realnego socjalizmu czy wytwarzane $\mathrm{w}$ sweat shopach dobra konsumpcyjne) nie jest usuwanych ze stworzonych przez nas zbiorowości. Decyduje o tym przede wszystkim to, że są one powiązane z nami silnymi relacjami, których podstawą jej nawyk, rutyna, przyzwyczajenie - aspekty sprawiające, iż znaczenia przez nie przenoszone stają się niewidoczne, albo przynajmniej drugorzędne. $Z$ tego typu rzeczami łączą nas związki czysto praktyczne, a nie ideologiczne, są więc one raczej narzędziami niż semioforami. Ich trwałość i nasze przywiązanie do nich stanowią zatem funkcję jednoznaczności tych obiektów w relacjach, którymi jesteśmy z nimi powiązani. 


\section{BIBLIOGRAFIA}

Abriszewski Krzysztof, 2008, Poznanie, zbiorowość, polityka. Analiza teorii aktora-sieci Bruno Latoura, Universitas, Kraków.

Appadurai Arjun (red.), 1986, The Social Life of Things: Commodities in Cultural Perspective, Cambridge University Pres, New York.

Barański Janusz, 2007, Świat rzeczy. Zarys antropologiczny, Wydawnictwo Uniwersytetu Jagiellońskiego, Kraków.

Campbell Colin, 2006, Kupuje, więc wiem, że jestem. Metafizyczne podstawy nowoczesnego konsumeryzmu, tłum. Maja Brzozowska-Brywczyńska, „Kultura Popularna”, nr 4.

Cassirer Ernst, 2001, Forma a technika, w: Erhard Schütz (red.), Kultura techniki. Studia i szkice, tłum. Izabela i Sven Sellmer, Wydawnictwo Poznańskie, Poznań.

Dant Tim, 2005, Materiality and Society, Open University Press, New York.

Domańska Ewa, 2006, Historie niekonwencjonalne. Refleksja o przeszłości w nowej humanistyce, Wydawnictwo Poznańskie, Poznań.

Du Gay Paul, Hall Stuart, Janes Linda, Mackay Hugh, Negus Keith, 1997, Doing Cultural Studies: The Story of the Sony Walkman, Sage, London-Thousand Oakes.

Emirbayer Mustafa, 1997, Manifesto for a Relational Sociology, „The American Journal of Sociology", t. 103, nr 2.

Freedberg David, 2005, Potęga wizerunków. Studia z historii i teorii oddziaływania, tłum. Ewa Klekot, Wydawnictwo Uniwersytetu Jagiellońskiego, Kraków.

Gell Alfred, 1998, Art and Agency: An Anthropological Theory, Clarendon Press, Oxford-New York.

Gibson James Jerome, 1977, The Theory of Affordances, w: Robert Shaw, John Bransford (red.), Perceiving, Acting, and Knowing: Toward an Ecological Psychology, Lawrence Erlbaum, Hillsdale, NJ.

Goldman Robert, Papson Stephen, 1999, Nike Culture: The Sign of the Swoosh Core Cultural Icons, Sage, London-New York.

Hebdige Dich, 1988, Hiding in the Light: On Images and Things, Routledge, London-New York.

Hobsbawm Eric, Ranger Terence (red.), 2008, Tradycja wynaleziona, tłum. Mieczysław Gogyń, Filip Godyń, Wydawnictwo Uniwersytetu Jagiellońskiego, Kraków.

Kahney Leander, 2005, The Cult of iPod, No Starch Press, San Francisco.

Kahney Leander, 2006, The Cult of Mac, No Starch Press, San Francisco.

Kaufmann Jean-Claude,2004, Ego. Socjologia jednostki, tłum. Krzysztof Wakar, Oficyna Naukowa, Warszawa.

Knappett Carl, 2005, Thinking Through Material Culture: An Interdisciplinary Perspective, University of Pennsylvania Press, Philadelphia.

Kopytoff Igor, 2004, Kulturowa biografia rzeczy: utowarowienie jako proces, tłum. Ewa Klekot, w: Marian Kempny, Ewa Nowicka (red.), Badanie kultury. Elementy teorii antropologicznej. Kontynuacje, Wydawnictwo Naukowe PWN, Warszawa.

Krajewski Marek, 2008, Przedmiot, który uczłowiecza, „Kultura Współczesna”, nr 3.

Lash Scott, Lury Celia, 2007, Global Culture Industry, Polity Press, Cambridge.

Lübbe Herman, 1988, Muzealizacja. O powiązaniu naszej teraźniejszości z przeszłościa, w: Maria Gołaszewska (red.), Estetyka w świecie, t. 3, Wydawnictwo Uniwersytetu Jagiellońskiego, Kraków. 
Mitchell W. J. T., 2005, What Do Pictures Want: The Lives and Loves of Images, University of Chicago Press, Chicago.

Pomian Krzysztof, 2006, Historia. Nauka wobec pamięci, Wydawnictwo UMCS, Lublin.

Rogers Mary Frances, 2003, Barbie jako ikona kultury, tłum. Ewa Klekot, Muza, Warszawa.

Schiffer Michael Brian, Miller Andrea R., 1999, The Material Life of Human Beings: Artifacts, Behavior, and Communications, Routledge, London-New York.

Schmidt Filip, Skowrońska Marta, 2008, Człowiek $w$ sieci przedmiotów. Socjologiczna analiza roli $i$ znaczenia przedmiotów w przestrzeni domowej, w: Jacek Kowalewski, Wojciech Piasek, Marta Sliwa (red.), Rzeczy i ludzie. Humanistyka wobec materialności, Instytut Filozofii Uniwersytetu Warmińsko-Mazurskiego, Olsztyn.

Thompson Michael, 1979, Rubbish Theory: The Creation and Destruction of Value, Oxford University Press, New York.

Ziółkowski Marek, 1994, Sprawowanie władzy a przekonania ludzkie, „Studia Socjologiczne", nr 2.

\section{THE LIFEWAYS OF OBJECTS, ON THE LONGEVITY OF MATERIAL GOODS}

\section{Summary}

The article comprises an attempt to answer the question why some material objects are, in a social and cultural sense, more long-lasting than others. The answer lies in the model of the life-space of the things. This space is created by two basic dimensions. The first is defined by the character of the relationships created by the objects (this dimension comprises the opposition between the technical relations versus the communicative ones). The second is defined by the character of the relationship between the body of the user and the material object (this is created by the opposition: accessible or inaccessible to sensory experience). The transition of the material object through this space is the life-way of the object, and it is precisely this which defines the longevity of the object and thus the length of time it persists within a specific community. The author determines that long-lasting objects are above all those which are linked with the community, or users, by single, unambiguous relationships and links, while those which have ambivalent and multiple links are of shorter lifespan. Whether or not a thing has a long life or not is determined therefore by the multiplicity of meanings it has which render impossible its role as a stabiliser of the links that constitute a community, as a foundation of the individual's identity, a guarantee of ontological security.

\section{Key words/słowa kluczowe}

material culture / kultura materialna; things / rzeczy; objects / przedmioty; the life of objects / życie przedmiotów; everyday life / codzienność; relationships / relacje 